\title{
CUB Domain-Containing Protein 1
}

National Cancer Institute

\section{Source}

National Cancer Institute. CUB Domain-Containing Protein 1. NCI Thesaurus. Code C95588.

CUB domain-containing protein 1 ( $836 \mathrm{aa}, \sim 93 \mathrm{kDa}$ ) is encoded by the human CDCP1 gene. This protein may play a role in matrix-dependent cell signaling. 